\title{
Investigasi Implementasi Model Discovery Learning Berbasis Pendekatan Saintifik Dalam Meningkatkan Aktivitas dan Hasil Belajar IPA
}

\author{
Sri Indarti ${ }^{1}$ \\ 1 SMP Negeri 24 Bandar Lampung \\ Coressponding Author. E-mail: \\ ${ }^{1}$ sindarti61@gmail.com \\ Received: 20 Juni 2019 \\ Accepted: 15 Juli 2019 Online Published: 20 Juli 2019
}

\begin{abstract}
Abstrak
Pada survey pendahuluan yang telah dilakukan di kelas, siswa memiliki pengetahuan kognitif dibawah Kriteria Ketuntasan Minimal yang telah ditetapkan sekolah. Penelitian ini bertujuan untuk meningkatkan aktivitas dan hasil belajar IPA peserta didik kelas VIIIA SMP Negeri 24 Bandar Lampung melalui penerapan model pembelajaran Discovery Learning dengan Pendekatan Saintifik. Penelitian ini menggunakan metode penelitian kuasi eksperimen. Subjek penelitian dalam penelitian ini adalah peserta didik kelas VIIIA SMP Negeri 24 Bandar Lampung Tahun Pelajaran 2017/2018 dengan jumlah peserta didik sebanyak 32 peserta didik dengan teknik pengambilan sampel cluster random sampling. Data yang diperlukan diperoleh melalui observasi, dokumentasi dan tes menggunakan soal-soal tes. Data yang terkumpul dianalisis dengan teknik analisis kualitatif dan kuantitatif. Hasil analisis deskriptif setelah penerapan model pembelajaran discovery learning dengan scientific approach ditunjukkan adanya peningkatan aktivitas dan hasil belajar peserta didik. Data hasil penelitian pada aktivitas belajar peserta didik menunjukkan adanya peningkatan dari pra penelitian yaitu $43,75 \%$ meningkat menjadi $78,13 \%$, sedangkan pada hasil belajar peserta didik menunjukkan peningkatan dari 66,25\% menjadi 78,13\%., sehingga diperoleh kesimpulan bahwa model pembelajaran Discovery Learning berbasis pendekatan saintifik dapat meningkatkan aktivitas dan hasil belajar peserta didik pada pembelajaran IPA di Kelas VIIIA SMP Negeri 24 Bandar Lampung Tahun Pelajaran 2017/2018
\end{abstract}

Kata Kunci: Discovery Learning; Hasil Belajar; Pembelajaran; Pendekatan Saintifik

\section{Investigation on the Implementation of Discovery Learning Model Based on Scientific Approach in Increasing Science Learning Activities and Outcomes}

\begin{abstract}
In the preliminary survey that has been done in class, students have cognitive knowledge under the Minimum Completion Criteria set by the school. This study aims to improve the activities and learning outcomes of science students of class VIII A SMP Negeri 24 Bandar Lampung through the application of the Discovery Learning model with the Scientific Approach. This research used quasi experiment research method. The research subjects in this study were students of class VIIIA SMP Negeri 24 Bandar Lampung Academic Year 2017/2018 with a total of 32 students with a cluster random sampling technique. The required data is obtained through observation, documentation and tests using test questions. The collected data was analyzed by qualitative and quantitative analysis techniques. The results of the descriptive analysis after the application of discovery learning models with the scientific approach showed an increase in activity and learning outcomes of students. Data from research results on student learning activities showed an increase from pre-study, namely $43.75 \%$, increased to $78.13 \%$, while the learning outcomes of students showed an increase from $66.25 \%$ to $78.13 \%$, so that it was concluded that Discovery Learning model based on scientific approach can improve the activities and learning outcomes of students in science learning in Class VIILA Public Middle School 24 Bandar Lampung Academic Year 2017/2018
\end{abstract}

Keywords: Discovery Learning; Learning Outcomes; Learning; Scientific Approach

How to cite this article :

Indarti, S. (2019). Investigasi Implementasi Model Discovery Learning Berbasis Pendekatan Saintifik Dalam Meningkatkan Aktivitas dan Hasil Belajar IPA. IJIS Edu : Indonesian Journal of Integrated Science Education, 1(2), 100-104. Retrieved from https://ejournal.iainbengkulu.ac.id/index.php/ijisedu/article/view/2244 


\section{PENDAHULUAN}

Proses pembelajaran dalam kurikulum 2013 diselenggarakan secara interaktif, inspiratif, menyenangkan, menantang, memotivasi peserta didik untuk berpartisipasi aktif, serta memberikan ruang yang cukup bagi prakarsa, kreativitas, dan kemandirian sesuai dengan bakat, minat, dan perkembangan fisik serta psikologis peserta didik. Penyusunan perencanaan pembelajaran, pelaksanaan proses pembelajaran, serta penilaian proses pembelajaran dengan strategi yang benar harus dipersiapkan dengan cermat agar dapat meningkatkan efisiensi dan efektivitas ketercapaian standar kompetensi lulusan.

Kurikulum 2013 mengamanatkan penggunaan pendekatan ilmiah. Pendekatan ilmiah (scientific approach) adalah pendekatan yang menonjolkan dimensi pengamatan, penalaran, penemuan, pengabsahan, dan penjelasan mengenai suatu kebenaran. Pendekatan ini memberi kesempatan untuk meningkatkan kemampuan peserta didik dalam melakukan observasi, bertanya, menalar, dan mengkomunikasikan pengetahuan yang diperoleh dari proses pembelajaran. Melalui tahapan-tahapan dalam pembelajaran yang berpendekatan scientific, peserta didik dibimbing secara bertahap untuk mengorganisasikan dan melakukan penelitian. Proses pembelajaran dengan scientific approach meliputi ranah kognitif, psikomotorik, dan afektif sehingga dapat membentuk peserta didik yang produktif, kreatif, inovatif, dan afektif melalui penguatan sikap, keterampilan, dan pengetahuan yang terintegrasi.

IPA sebagai salah satu mata pelajaran dalam satuan pendidikan di SMP juga harus mampu melaksanakan amanat tersebut. IPA merupakan ilmu yang diperoleh dan dikembangkan berdasarkan eksperimen untuk mencari jawaban atas pertanyaan apa, mengapa, dan bagaimana gejala-gejala alam berlangsung, khususnya yang berkaitan dengan zat (Depdikbud, 2003).

Berdasarkan hasil tes evaluasi belajar IPA diperoleh gambaran diperoleh data tes studi awal ternyata hasil belajar masih rendah, yang terlihat dari belum tercapainya ketuntasan individu dan ketuntasan klasikal dalam pembelajaran seperti yang diharapkan. Dari 32 orang peserta didik kelas VIII A SMP Negeri 24 Bandar Lampung sebanyak 16 orang peserta didik atau sebesar $50,00 \%$ memperoleh nilai di bawah KKM, dan hanya sebanyak 16 orang peserta didik atau sebesar $50,00 \%$ saja peserta didik yang memperoleh nilai $\geq$ KKM 75 dan pencapaian ketuntasan tersebut masih berada di bawah hasil yang diharapkan yaitu lebih dari 85\% peserta didik yang mencapai ketuntasan. dengan perolehan nilai rata-rata secara klasikal mencapai angka 66,25.

Gambaran hasil tersebut menunjukkan meskipun sudah dikaitkan dengan hal-hal yang ada dalam kehidupan sehari-hari peserta didik masih pasif dalam proses pembelajaran. Guru berfungsi sebagai sumber belajar utama yang menyajikan pengetahuan IPA kepada peserta didik kemudian peserta didik hanya memperhatikan penjelasan dan contoh yang diberikan oleh guru tanpa terlibat langsung dalam penemuan dan pengonstruksian pengetahuan. Kegiatan pembelajaran masih kurang mengembangkan proses interaksi antar peserta didik, antara peserta didik dengan guru, dan sumber belajar pada suatu lingkungan.

Dalam mengatasi permasalahan tersebut di atas perlu dilakukan pembelajaran yang dapat mendukung pemahaman konsep-konsep IPA dengan baik antara lain penggunaan model pembelajaran Discovery Learning yang merupakan bagian dari pembelajaran yang berpusat pada peserta didik. Pembelajaran yang berpusat pada peserta didik (Student-Centered Leaning), peserta didik diharapkan sebagai peserta aktif dan mandiri dalam proses belajarnya, yang bertanggung jawab dan berinitiatif untuk mengenali kebutuhan belajarnya, menemukan sumber-sumber informasi untuk dapat menjawab kebutuhannya, membangun serta mempresentasikan pengetahuannya berdasarkan kebutuhan serta sumber-sumber yang ditemukannya (Pongtuluran, 2000). Penelitian ini bertujuan untuk meningkatkan aktivitas dan hasil belajar IPA peserta didik kelas VIIIA SMP Negeri 24 Bandar Lampung melalui penerapan model pembelajaran Discovery Learning dengan Pendekatan Saintifik

\section{METODE}

Penelitian ini dirancang menggunakan quasi eksperimental design. Penelitian ini dilaksanakan di kelas VIIIA SMP Negeri 24 Bandar Lampung. Populasi penelitian ini adalah semua peserta didik kelas VIIIA SMP Negeri 24 Bandar Lampung tahun ajaran 2017/2018, pada semester ganjil dari bulan Agustus sampai September dengan materi "Sistem Pencernaan Makanan". Teknik pengambilan sampel yang digunakan adalah teknik cluster random sampling. Sampel penelitian terdiri dari 2 kelas yaitu kelas VIIIA menggunakan metode Discovery learning dengan jumlah peserta didik 20 orang atau sebagai kelas eksperimen dan kelas VIIIB menggunakan model pembelajaran Konvensional atau sebagai kelas kontrol dengan jumlah peserta didik 20 orang. Variabel bebas 
(Independent variable) dalam penelitian ini adalah metode pembelajaran discovery. Variabel terikat (dependent variable) dalam penelitian ini adalah aktivitas dan hasil belajar. Teknik-teknik yang digunakan untuk mengumpulkan data adalah Instrumen Tes yang diberikan sebelum (pretest) dan setelah (posttest) proses pembelajaran pada kelas eksperimen dan kelas kontrol.

Indikator yang digunakan untuk mengukur hasil belajar peserta didik adalah Instrumen tes hasil belajar peserta didik. Instrumen tes hasil belajar terlebih dahulu di validiasi, di uji reliabilitas, menghitung daya pembeda dan tingkat kesukaran soal.

\section{HASIL DAN PEMBAHASAN}

Adapun penjelasan mengenai hasil observasi terhadap aktivitas peserta didik selama mengikuti kegiatan pembelajaran yang dinilai menggunakan 7 indikator yaitu 1) Peserta didik membaca materi yang akan dipelajari. 2) Peserta didik berdiskusi dengan teman. 3) Peserta didik bertanya pada guru atau teman. 4) Peserta didik menyimak penjelasan dari guru. 5) Peserta didik membuat catatan tentang materi pelajaran. 6) Peserta didik menanggapi pendapat teman atau guru. 7) Peserta didik mengerjakan tes dengan kemampuan sendiri sebagaimana dijelaskan pada tabel 1.

Tabel 1. Rekapitulasi Hasil Observasi Peningkatan Aktivitas Peserta didik dalam Kegiatan Pembelajaran pada Kondisi Awal

\begin{tabular}{ll}
\hline Uraian & Jumlah \\
\hline Peserta didik Tuntas & 14 \\
\hline Persentase Tuntas & 43,75 \\
\hline Peserta didik Belum Tuntas & 18 \\
\hline Persentase Belum Tuntas & 56,25 \\
\hline Ketuntasan Klasikal & 43,75 \\
\hline
\end{tabular}

Berdasarkan data yang terlampir dalam tabel 1, dari 7 indikator yang diamati oleh peneliti, data tersebut menunjukkan bahwa peserta didik yang dinyatakan tuntas hanya sebanyak 14 peserta didik atau $43,75 \%$ dan sisanya sebanyak 18 peserta didik atau $56,25 \%$ dinyatakan belum tuntas.

Pembelajaran dengan pendekatan Discovery Learning merupakan model pembelajaran kooperatif untuk pengelompokan campur yang melibatkan pengakuan tim dan tanggung jawab kelompok untuk pembelajaran individu anggota. Pada pendekatan Discovery Learning dibuat kelompok-kelompok. Peserta didik diberikan kebebasan untuk mengemukakan pendapat, berdiskusi, bertanya kepada teman satu timnya, untuk menyelesaikan suatu masalah yang kemudian hasilnya dipresentasikan di depan kelas oleh perwakilan tim dan indikator proses pembelajaran.

Tabel 2. Rekapitulasi Hasil Observasi Peningkatan Aktivitas Peserta didik dalam Kegiatan

Pembelajaran dengan Metode Discovery Learning

\begin{tabular}{ll}
\hline Uraian & Jumlah \\
\hline Peserta didik Tuntas & 25 \\
\hline Persentase Tuntas & 78,13 \\
\hline Peserta didik Belum Tuntas & 7 \\
\hline Persentase Belum Tuntas & 21,87 \\
\hline Ketuntasan Klasikal & 78,13 \\
\hline
\end{tabular}

Dari tabel 2, dapat disimpulkan bahwa dari 32 peserta didik terdapat 25 orang yang tuntas belajarnya $(78,13 \%)$ dilihat dari aktivitas belajarnya, sedangkan 7 peserta didik $(21,87 \%)$ belum tuntas dilihat dari aktivitas belajarnya. Peningkatan aktivitas belajar cukup signifikan pada setiap siklusnya, dimana pada studi awal hanya 43,75\% atau 14 peserta didik, meningkat menjadi 78,13\% atau 25 peserta didik. Sepertinya halnya peningkatan aktivitas belajar, hasil belajarpun meningkat cukup baik, yaitu dari nilai rata-rata hasil belajar sebesar 66,25 meningkat menjadi 72,81.

Berdasarkan penelitian yang telah dilakukan, penerapan model pembelajaran discovery learning dalam pembelajaran IPA materi keseimbangan dan dinamika rotasi di kelas VIII A SMP Negeri 24 Bandar Lampung dapat meningkatkan aktivitas dan hasil belajar peserta didik. Jika menerapkan pendekatan saintifik dengan model pembelajaran discovery learning maka guru harus merencanakan dan mempersiapkan kegiatan pembelajaran yang akan dilaksanakan secara matang. Persiapan guru antara lain tentang bagaimana guru membangkitkan motivasi peserta didik, bagaimana guru menyampaikan materi, bagaimana guru mengatur latar pembelajaran kelas, serta bagaimana guru membimbing peserta didik dalam kegiatan kelompok.

Motivasi yang ada pada diri peserta didik sangat menentukan respon mereka terhadap keberlangsungan pembelajaran. Jika guru melakukan apersepsi dengan baik maka kemungkinan peserta didik untuk merespon kegiatan pembelajaran akan baik. Guru melakukan apersepsi dengan menampilkan media berupa

102 http://ejournal.iainbengkulu.ac.id/index.php/ijisedu 
gambar, video, dan benda konkret yang berkaitan dengan materi pembelajaran. Selain itu juga dihadirkan berbagai macam tepuk tangan atau dapat juga melalui lagu. Jika guru menggunakan model pembelajaran discovery learning, maka guru perlu mempersiapkan sarana dan prasarana yang memadai karena pada tahap penyajian materi guru harus fokus terhadap pokok materi yang dipelajari. Materi globalisasi erat kaitannya dengan kehidupan Dalam kesehariannya guru perlu memilih dan mengembangkan media pembelajaran yang sesuai dengan pembelajaran yang akan dilakukan saat itu. Misalnya, media gambar, benda-benda konkret, dan LCD projector yang dapat digunakan untuk membantu pengajuan permasalahan serta penyampaian materi kepada peserta didik materi keseimbangan dan dinamika rotasi . Jika guru menggunakan model pembelajaran model pembelajaran discovery learning, maka guru harus menyusun dan mengembangkan materi.

Pada model pembelajaran discovery learning, alokasi waktu bagi guru untuk menyampaikan materi tidak banyak. Hal ini dikarenakan pembelajaran discovery learning menekankan pada kemampuan dan aktivitas peserta didik dalam kegiatan pembelajaran. Pengembangan materi diwujudkan guru dalam bentuk tugas kelompok yang diberikan sehingga dapat memberikan kesempatan kepada peserta didik untuk mendiskusikan dengan kelompoknya. Tiap peserta didik memiliki pendapat dan cara yang berbeda dalam menyelesaikan persoalan yang diberikan. Jika guru menggunakan model pembelajaran discovery learning maka guru harus memperhatikan karakteristik peserta didik, karena merupakan kelompok yang heterogen. Model pembelajaran discovery learning akan melatih peserta didik fokus terhadap pokok materi yang sedang dikaji.

Penerapan model pembelajaran discovery learning dalam pembelajaran IPA materi keseimbangan dan dinamika rotasi di kelas VIII A SMP Negeri 24 Bandar Lampung ini mampu membantu peserta didik mengaitkan materi yang dipelajari dengan lingkungannya, sehingga pembelajaran lebih bermakna dan mudah dipahami. Penerapan model pembelajaran ini membuat peserta didik menjadi lebih aktif dalam mengumpulkan data untuk memahami konsep keseimbangan dan dinamika rotasi .Kegiatan berkelompok mengasah kemampuan peserta didik berpendapat dan memahami suatu persoalan dari segi positif dan negatif, sehingga peserta didik memahami mana yang baik dan mana yang buruk serta penerapannya dalam kehidupan sehari-hari. Oleh karena itu, guru harus memberikan bimbingan yang menyeluruh kepada setiap kelompok untuk saling bekerjasama, sehingga semua anggota kelompok terlibat aktif dalam proses belajar.

\section{SIMPULAN}

Dari hasil penelitian menunjukkan adanya peningkatan aktivitas belajar peserta didik pada setiap indikatornya. Hal ini membuktikan bahwa model pembelajaran Discovery Learning dengan pendekatan saintifik mampu meningkatkan aktivitas dan hasil belajar peserta didik. Peningkatan aktivitas belajar peserta didik juga didukung dengan meningkatnya hasil belajar peserta didik.

\section{DAFTAR PUSTAKA}

Akella, L. M., Norton, C. N., \& Miller, H. (2012). NetiNeti: discovery of scientific names from text using machine learning methods. $B M C$ Bioinformatics, $\quad 13(1), \quad 211$. https://doi.org/10.1186/1471-2105-13-211

Amin, A. (2017a). Pemahaman Konsep Abstrak Ajaran Agama Islam pada Anak Melalui Pendekatan Sinektik dan Isyarat Analogi dalam Alquran. MADANIA: JURNAL KAJLAN KEISLAMAN, 21(2), 157. https://doi.org/10.29300/madania.v21i2.6 08

Amin, A. (2017b). PENGEMBANGAN BAHAN AJAR PAI ASPEK AKHLAQ BERBASIS PENDEKATAN PEMBELAJARAN DEMOKRATIK DALAM MENINGKATKAN PEMAHAMAN KONSEP SISWA SMPN 12 KOTA BENGKULU. Manhaj: Jurnal Penelitian Dan Pengabdian Masyarakat, 2(3). https://doi.org/10.1161/.V5I3.755

Amin, A., Wiwinda, W., Alimni, A., \& Yulyana, R. (2018). Pengembangan Materi Pendidikan Agama Islam Berbasis Model Pembelajaran Inquiry Training Untuk Karakter Kejujuran Siswa Sekolah Menengah Pertama. AtTa'lim: Media Informasi Pendidikan Islam, 17(1). Retrieved from http://ejournal.iainbengkulu.ac.id/index.ph $\mathrm{p} /$ attalim/article/view/1418 
Azkiya, H., \& Isnandab, R. (2019). PENGARUH MODEL PEMBELAJARAN DISCOVERY LEARNING TERHADAP KETERAMPILAN MENULIS TEKS EKSPLANASI SISWA KELAS VII MTsN DURIAN TARUNG PADANG. BAHASTRA, 38(2), 95. https://doi.org/10.26555/bahastra.v38i2.8 495

DeDonno, M. A. (2016). The influence of IQ on pure discovery and guided discovery learning of a complex real-world task. Learning and Individual Differences, 49, 11-16. https://doi.org/10.1016/J.LINDIF.2016.0 5.023

Hong, Y., Hao, Z., Mai, G., Huang, H., \& Kumar Sangaiah, A. (2018). Causal Discovery Combining K2 with Brain Storm Optimization Algorithm. Molecules, 23(7), 1729.

https://doi.org/10.3390/molecules230717 29

Imawan, O. R. (2015). Perbandingan antara Keefektifan Model Guided Discovery Learning dan Project-Based Learning pada Matakuliah Geometri. PYTHAGORAS: Jurnal Pendidikan Matematika, 10(2), 179. https://doi.org/10.21831/pg.v10i2.9156

Jalil, M. (2016). PENGEMBANGAN PEMBELAJARAN MODEL DISCOVERY LEARNING BERBANTUAN TIPS POWERPOINT INTERAKTIF PADA MATERI INTERAKSI MAKHLUK HIDUP DENGAN LINGKUNGAN. REFLEKSI EDUKATIKA, https://doi.org/10.24176/re.v6i2.604 $6(2)$.

$\begin{array}{cr}\text { Mahyudin, E. } & \text { MODEL } \\ \text { PEMBELAJARAN } & \text { DISKOVERI } \\ \text { SEBAGAI } & \text { STRATEGI } \\ \text { PEMBELAJARAN } & \text { BAHASA ARAB. } \\ \text { ARABIYAT: Jurnal Pendidikan Bahasa Arab } \\ \text { Dan Kebahasaaraban, 1(2), 195-208. } \\ \text { https://doi.org/10.15408/a.v1i2.1139 }\end{array}$

Rudyanto, H. E. (2016). MODEL DISCOVERY LEARNING DENGAN PENDEKATAN SAINTIFIK BERMUATAN KARAKTER UNTUK MENINGKATKAN KEMAMPUAN BERPIKIR KREATIF. Premiere Educandum: Jurnal Pendidikan Dasar Dan Pembelajaran, 4(01). https://doi.org/10.25273/pe.v4i01.305

Sukmadinata, N. S. (2009). Metode Penelitian Pendidikan. Bandung: Remaja Rosdakarya.

Vahlia, I., Rahmawati, Y., \& Anjar, T. (2017). EFEKTIVITAS PENDEKATAN SAINTIFIK BERBASIS GROUP INVESTIGATION DAN DISCOVERY LEARNING DITINJAU DARI MINAT BELAJAR MAHASISWA. AKSIOMA: Jurnal Program Studi Pendidikan Matematika, 6(1), 128. https://doi.org/10.24127/ajpm.v6i1.909

Valmarska, A., Lavrač, N., Fürnkranz, J., \& Robnik-Šikonja, M. (2017). Refinement and selection heuristics in subgroup discovery and classification rule learning. Expert Systems with Applications, 81, 147-162. https://doi.org/10.1016/J.ESWA.2017.03. 041

Walid, A., Sajidan, S., Ramli, M., \& Kusumah, R. G. T. (2019). Construction of the assessment concept to measure students' high order thinking skills. Journal for the Education of Gifted Young Scientists, 7(2). https://doi.org/10.17478/jegys.528180

Walid, Ahmad, Putra, E. P., \& Asiyah. (2019). Pembelajaran Biologi Menggunakan Problem Solving Disertai Diagram Tree Untuk Memberdayakan Kemampuan Berpikir Logis Dan Kemampuan Menafsirkan Siswa. IJIS Edu: Indonesian Journal of Integrated Science Education, 1(1), 1-6. Retrieved from http://ejournal.iainbengkulu.ac.id/index.ph $\mathrm{p} /$ ijisedu 